\title{
Experimental Organism Islet Cell Adenoma Neoplasm
}

National Cancer Institute

\section{Source}

National Cancer Institute. Experimental Organism Islet Cell Adenoma Neoplasm. NCI

Thesaurus. Code C114108.

A benign neoplasm arising from the islet cells of the pancreas. 